\section{IJßER}

ISSN: 2149-5939
International Journal of Social Sciences and Education Research

Online, http://dergipark.gov.tr/ijsser

Volume: 3(1), 2017

\title{
Üniversite gençlerinin yalnızlık ve utangaçlık unsurları açısından akıllı telefon bağımlılı̆̆
}

\author{
Smartphone addiction in terms of the elements of loneliness and shyness of \\ university youth
}

\begin{abstract}
Hasret Aktaş ${ }^{1}$
Nurcan Yilmaz

Received Date: 01 / 09 / 2016

Accepted Date: $15 / 12$ / 2016

$\ddot{\boldsymbol{O}}$

Cep telefonu ve avuç içi bilgisayar teknolojilerini tek bir cihaz içine birleştiren akall telefonlar günümüzün popüler teknolojik araçları konumundadır. Yeni nesil teknolojinin temel hedef kitlesi ve kullanıcısı konumunda olan üniversite öğrencilerinin iletişim ve bilişim teknolojilerine yönelik ilgi ve merakları sayesinde, akıllı telefon gibi işlevselliği daha yüksek olan araçların günlük kullanım süreleri hızla artmaktadır. Bu araçların uzun süreli kullanımı akıllı telefon bağımlılı̆̆ sorununu ortaya çıkarmaktadır. Çalışmanın amacı, akıllı telefon bağımlılık düzeyini utangaçlık ve yalnızlık açısından ölçmektir. Araştırmanın örneklemini Selçuk Üniversitesi İletişim Fakültesinde eğitim gören ve akıllı telefon kullanıcısı olan üniversite öğrencisi oluşturmaktadır. Çalışmada Akıllı Telefon Bağımlılık Ölçeği, UCLA Yalnızlık Ölçeği ve Utangaçlık Ölç̧eği kullanılarak veriler elde edilmiştir. Elde edilen veriler ışığında faktör analizi, korelasyon analizi ve regresyon analizi gibi analizler kullanılmıștır. Analiz sonuçlarına göre; öğrenciler, akıllı telefonu daha çok internette gezinmek, sosyal ă̆ hizmetlerini kullanmak ve müzik dinlemek amaçlı kullanırken, oyun oynamak ve e-kitap okumak için daha az kullanmaktadır. Akıllı telefon bağımlılı̆̆ faktörleri ile yalnızlık ve utangaçlık arasında pozitif anlamlı ilişki vardır. Ayrıca regrasyon analizindeki bağımlı değiş̧kenlerin bağımsız değişkeni pozitif yönde ve anlamlı düzeyde yordadı̆̆ görülmektedir.
\end{abstract}

Anahtar Sözcükler: Akıllı telefon bă̆ımlılı̆̆l, yalnızlık, utangaçlık.

\begin{abstract}
Smartphones which combine cell phone and palmtop computer technology into a single device are popular technological tools of today. University students' within the user location and main target group of the new generation of technology thanks to interest and curiosity for communication and information technology are rapidly increasing duration of use daily tools which have higher functionality such as smartphones. Long-term usage of this tools has raised the issue of smartphone addiction. The purpose of this study is to examine smartphone addiction level in terms of shyness and loneliness. The sample of the study consists of students in college who are smartphone users and studying at Communication Faculty of Selcuk University. In the study, the data will be obtained using Smart Phone Addiction Scale, UCLA Loneliness Scale and Shyness Scale. In the light of the data obtained, in analyses such as factor analysis, correlation analysis and regression analysis were used. According to the results of the analysis; students use less to play the game and read e-books while using a purpose to more surf the web, to use social networking services and listen to music. Smart phone addiction a significant positive correlation between shyness and loneliness factors. There is a significant positive correlation between loneliness and shyness with smart phone addiction factors. Also "information/the entertainment, shyness and loneliness of the differentiating variables makes it different which is variable positively and significantly, it is observed that smartphone addiction. In addition, the dependent variables in the regression analysis are positively and significantly affected in the independent variable.
\end{abstract}

Keywords: Smartphone addiction, loneliness, shyness.

\footnotetext{
${ }^{1}$ Doç. Dr., Selçuk Üniversitesi İletişim Fakültesi, Konya/TÜRKIYY h.aktas @selcuk.edu.tr

${ }^{2}$ Arş. Grv. İnönü Üniversitesi İletişim Fakültesi, Malatya/TÜRKIYE, nurcan.gunay@inonu.edu.tr
} 
Aktaş, H., Yılmaz, N. (2017). Üniversite gençlerinin yalnızlık ve utangaçlık unsurları açısından akıllı telefon bağımlılığı. International Journal of Social Sciences and Education Research, 3(1), 85-100.

\section{Giriş}

Son on yıl içinde, cep telefonları dünya çapında hızlı bir şekilde yaygın hale gelmiştir. Cep telefonu hayatımıza ilk girdiğinde öncelikli olarak mobil olma ve iletişimi yaşamın her alanına her saniye taşıyabilme özelliğine sahipken bilgi ve iletişim teknolojilerindeki gelişmelerle birlikte artık mobil iletişim araçları, kullanıcılar için bilgiye daha hızlı ve kolay erişim olanağı sunar hale gelmiştir. Artık cep telefonları iletişim kurma ihtiyacını gidermenin ötesinde fotoğraf çekme, video kayıt, müzik dinleme, yön bulma aracı olarak kullanma, internete erişim ve görüntülü konuşma gibi birçok ihtiyacı da karşılayan, hatta egzersizlerimiz sırasında kalp atışlarımızı sayan, adeta günlük hayatımızın vazgeçilmezi olan iletişim araçlarıdır.

Teknolojik gelişmelerle, daha güçlü, daha kolay kullanımı olan, uygun bir şekilde taşınabilir ve daha kişisel, daha küçük gelişmiş araçlar ortaya çıkmıştır. Bunun için en güzel örnek, cep telefonu ve avuç içi bilgisayar teknolojilerini tek bir cihazda buluşturan akıllı telefonlardır (Chen vd., 2011:422). 1996 yılından beri cep telefonu pazarında en hızlı büyüyen yeni teknolojilerden biri olma özelliğini taşıyan akıllı telefonlar (Choudrie vd.,2014:1), herhangi bir şey hakkında bir soru sormak için sesli arama ve GPS navigasyon sistemi, kamera ve video kamera, müzik çalar ve film oynatma, web ve e-mail için internet erişimi gibi birçok özelliği hücresel telefonlarla birleştiren kişisel bir yardımcı gibidir. Bilgi paylaşımı, e-postaları gönderme ve alma, sohbet etme, belgelerin açılması ve düzenlenmesi, gözden geçirme ve alışveriş yapma, ürünler için ödeme yapma gibi normal bilgisayarlarda yapılabilir tüm faaliyetler akıllı telefon kullanılarak yapılabilmektedir (Alfawareh ve Jusoh, 2014:321). Çünkü akıllı telefon artık ana iletişim aracı olarak kullandığımız ve üstelik seyahat ettiğimiz tüm zamanlarda bizimle birlikte olma özelliğine sahip bir araçtır. Ekran boyutunda bir sınırlama olmasına rağmen, giderek daha iyi ses tanıma özelliği ile yazmayı ortadan kaldırmakta, büyük ekranlarda özellikle metin okuma, video izleme de mümkün ve kolay olmaktadır.

İlginç bir şekilde modern toplumda birçok kişi yoğun olarak akıllı telefon satın almayla ilgilenmekte, kimi zaman fiyat ve özellikleriyle ilgili gelişmeleri an be an takip etmektedir (Kwon vd., 2013:1-2). International Data Corporation (IDC) analiz şirketinin akıllı telefon pazarına yönelik yayınladığı beş yıllık (2016-2020) tahmini raporuna göre, 2015 yılında 1,44 milyar olan akıllı telefon pazarının 2016 sonu itibariyle toplam 1,48 milyar olacăğ 2020 yılında ise akıllı telefon pazar payının 1,84 milyara ulaşacağı öngörülmektedir (IDC, 2016). Türkiye İstatistik Kurumu 2015 yılı Nisan ayı verilerine göre, hanelerin \% 96,8'inde cep telefonu veya akıllı telefon bulunmaktadır (TÜİK, 2015). Pew Araştırma Merkezi'nin Mart-Mayıs 2015 'te gelişmekte olan ve gelişmiş 40 ülkede yapmış olduğu araştırma sonuçlarına göre, son 2 yılda internet kullanım ve akıllı telefon sahipliği oranının önemli derecede arttığı ortaya çıkmıştır. Akıllı telefona sahip olma oranı en çok zengin ekonomilerde görülmektedir. Akı1lı telefona sahip olmanın yüksek olduğu ülkeler arasında \% 88 ile Güney Kore ilk sırayı almaktadır. Bu ülkeyi sırasıyla \% 77 ile Avustralya, \% 74 ile İsrail, \% 72 ile Amerika ve \% 71 ile İspanya takip etmektedir. Türkiye \% 59 oran ile 12. sirada yer almaktadır (Poushter, 2016). Akıllı telefonlar beklenmedik bir hızda benimsenme oranıla tarihteki tüm diğer taşınabilir dijital cihazları geride bırakmıştır (Chun vd., 2012:473). Türkiye'de 1994 yılında başlayan cep telefonu piyasası faaliyetleri özellikle genç yaşta olanların talebiyle sürekli gelişme göstermiştir. Cep telefonu talep eden gençler arasında ise üniversite öğrencileri önemli bir müşteri grubunu oluşturmaktadır (Uzgören vd., 2013:30). 
Aktaş, H., Yılmaz, N. (2017). Smartphone addiction in terms of the elements of loneliness and shyness of university youth. International Journal of Social Sciences and Education Research, 3(1), 85-100.

\section{Kavramlar ve literatür taraması}

Akıllı telefonlar ile ilgili bağımlılık kavramına ek olarak yalnızlık ve utangaçlık konuları bu başlık altında değerlendirilmiştir.

\subsection{Akıllı telefon bă̆gmlılı̆g}

Akıllı telefonlar taşıdıkları özelliklerle kullanıcıların fonksiyonel ve duygusal ihtiyaçlarına hitap etmektedir. Kimi zaman ürün ve kullanıcı arasındaki etkileşim kullanıcıların niyet ve davranışını etkilemektedir (Jin vd., 2013:563). Bugünün gençleri yeni nesil ileri teknoloji araçlarının çeşitli formlarıyla çevrili olan bir ortamda büyüdüğü için akıllı telefonlar gibi araçların yeni formlarına son derece açık olmaktadır. Bu da ileri yaş gruplarına göre gençlerin akıllı telefonların yan etkilerine karşı daha hassas oldukları anlamına gelmektedir. Akıllı telefon kullanımı, birçok insan için hayatı daha kolay hale getirmesine rağmen aynı zamanda psikolojik açıdan bazı sorunlara da yol açmıştır. Bunun için belirtilebilecek en önemli sorun, akı1lı telefon bağımlılığıdır. Akıllı telefon bağımlılığı görece yeni bir olgu olduğu için bu bağımlılık türünün belirtilerini tanımlayan çalışmalar da azdır (Kim vd., 2014:1).

Bağımlılık, genelde kişinin biyolojik ya da genetik yatkınlığı, psikolojik bünyesi, sosyal çevresi ve faaliyetin kendi doğasını içeren birçok faktör arasındaki karşılıklı etkileşimden kaynaklanmaktadır (Griffiths, 2003:558-559). Lee (2006)'ye göre, günümüzde bağımlılık sadece ilaç veya uyuşturucu madde kullanma anlamına gelmemekte, aynı zamanda kumar oynama, internet, oyunlar, hatta akı1lı telefonlara olan düşkünlük anlamına da gelmektedir. Bunlar da davranışsal bağımlılık kategorisi altında yer almaktadır (akt. Kwon vd., 2013:1).

Akıllı telefonlar giderek daha geniş kullanım durumları için daha fazla uygulama sağladığından insanların günlük yaşamının ayrılmaz bir parçası haline gelmiştir (Alfawareh ve Jusoh, 2014:321). Artık her konuda akıllı telefondan yardım alınmakta, not almak yerine hemen telefonla fotoğraf çekilmekte, hatta artık derslerde bile not tutmak yerine sunuların ya da materyallerin fotoğrafları çekilmektedir. Fakat şu da bir gerçektir ki; bir cihaza böyle bir bağımlılığın olması ayrıca pek çok risk oluşturabilmektedir.

Son zamanlarda "akıllı telefon bağımlılığı" birçok toplumda önemli bir konu haline gelmiş, oyun, sohbet ve porno gibi internet temelli faaliyetlerin ilaç ve maddenin kötüye kullanımındaki gibi bağımlılıkla benzer seviyelerde gösterildiği rapor edilmiştir. Gelişmiş bilişim teknolojileri sektöründeki bağımlılığın bu yeni türüne internet ve akıllı telefonların dahil olduğu hızla gelişen araçlar neden olmuştur (Kwon vd., 2013:1).

\subsection{Yalnızlık}

Yalnızlık, bir kişinin sosyal ilişkiler ağında ya niceliksel ya da niteliksel olarak bazı önemli eksiklikleri olduğu durumlarda ortaya çıkan, hoşa gitmeyen bir deneyim olarak tanımlanmıştır. Yalnızlıkla ilgili bu tanım içinde üç önemli nokta yer almaktadır: Birincisi, yalnızlık kişinin sosyal ilişkilerindeki eksikliklerinden kaynaklanır, ikincisi, yalnızlık öznel bir olgudur (mutlaka nesnel izolasyonla aynı anlama gelmediği, insanların yalnız olmadan da kendini yalnız hissedebildiği), son olarak yalnızlığın hoş olmayan ve üzüntü veren bir duygu olduğudur (Perlman ve Peplau 1981:31-32). Günümüzde, kişilerarası ilişkiler birçok sebepten dolayı bozulmakta ve yakınlıktan mahrum olan insanların sayısında hızlı bir artış gözlenmektedir. Yalnızlık da bireyin yaşamını olumsuz olarak etkileyen, gün geçtikçe artan 
Aktaş, H., Yılmaz, N. (2017). Üniversite gençlerinin yalnızlık ve utangaçlık unsurları açısından akıllı telefon bağımlılı̆̆. International Journal of Social Sciences and Education Research, 3(1), 85-100.

önemli bir problem olarak karşımıza çıkmaktadır (Kılınç ve Seher, 2005:72-73). Kalıcı yalnızlık, depresyon, intihar riskini arttırma ve diğer şekillerde psikolojik sağlığı tehlikeye sokacak eylem ve davranışlara zemin hazırlamaktadır (Perlman ve Peplau 1984:14). Ayrıca yalnızlığın, alkol bağımlılığı dahil ergenlerin davranışlarının suça yönelmesi, fiziksel hastalık ve sağlı hizmetlerinin aşırı kullanımı gibi diğer ciddi bireysel ve toplumsal sorunlarla çeşitli bağlantıları bulunmaktadır (Russell vd. 1980:472).

Jones vd., (1982) ve Spitzberg ve Canary (1985)'nin yapmış olduğu çalışmalar, yalnız insanların kişilerarası iletişim ve ilişkileri ile ilgili sorunları olduğunu tutarlı bir şekilde ortaya koymuştur. Tsai ve Reis (2009), sosyal algılar açısından yalnız insanların, yalnız olmayan insanların yaptığından daha olumsuz (daha az arkadaş canlısı) bir şekilde kendilerini diğer kişilere gösterme eğiliminde olduğunu belirlemiştir. Sloan ve Solano (1984)'ya göre, davranışsal olarak, yalnız insanlar daha az konuşma eğilimindedir. Yalnız insanların ilgi ve katılımı daha düşük seviyelerdedir (akt. Jin ve Park, 2012: 1095-1096). Engelberg ve Sjörberg (2004), daha zayıf sosyal becerilere sahip yalnız insanların interneti daha sik kullanma eğiliminde olduklarını bulmuşlardır. Park (2005), Kore'de yapmış olduğu çalışmada, üniversite öğrencileri arasında cep telefonu bağımlılığı ile yalnızlık arasında pozitif bir ilişki olduğunu belirlemiştir (akt. Bian ve Leung, 2014:3). Yalnız insanlar, yüz yüze iletişimde başkalarıyla konuşmakta isteksiz olduklarından akıllı telefonlardaki diğer ağ uygulamalarına yönelmektedir ve insanlarla mesajlaşarak iletişim kurmayı tercih eden bir eğilimde olmaktadır (Bian ve Leung, 2014:3).

\subsection{Utangaçlık}

Pilkonis (1977:596) utangaçlığı, sosyal etkileşimlerden kaçınma ve sosyal ortamlara uygun olarak katılmada başarısız olma eğilimi olarak tanımlamaktadır. Yaygın görüş olarak utangaçlık, ne düşündüğünü açıkça söyleyememek ve sosyal hayata özgür bir şekilde katılamamanın ötesinde, kendini gerçekleştirme ve başarı için bir engel hatta

ahlaki başarısızlık olarak kabul edilmektedir. Birçok kişi engellenme, endişe ya da mahcubiyet gibi duygularla sosyal ortamlarda zaman zaman utangaçlık yaşarken, kendileri ve başkaları tarafından utangaç kişiler olarak tanımlanmaktadır (Rouse, 2008:344). Utangaçlık, bireyin yeni insanlarla tanışmasını, yeni arkadaşlar edinmesini ve farklı yaşantılardan zevk almasını zorlaştıran en önemli etmen olarak görülmektedir (Pilkonis, 1977:605). Bu durum onların yalnızlığa itilmelerine ve kendilerini yalnız hissetmelerine neden olmaktadır (Yüksel, 2002:38). Farklı araştırmalardan elde edilen bulgular, internet kullanım sıklığ ve utangaçlık arasındaki ilişkiyi işaret etmektedir. Utangaç insanlar genellikle daha küçük arkadaşlık ağlarına, daha az sosyal desteğe, azalmış sosyal etkileşime, zayıf sosyal ilişkilere ve iletişim eksikliğine sahiptir. Utangaç insanlar, kendine daha az güvenen ve daha az yetenekli olma eğilimindedir (Huan vd., 2014:701).

Akıllı telefonlar daha önceden de belirtildiği gibi sadece sözlü iletişim sağlamaz aynı zamanda sosyal ağlar için fonksiyonlara sahiptir. Özellikle gençlerin bol miktarda kullandığı Whatsapp, Wechat, hatta Bip ve Snapchat gibi mesajlaşma uygulamaları bulunmaktadır. Bu uygulamalar insanların başkalarıyla yüz yüze ya da sözlü iletişimden kaçınmasına olanak sağlamaktadır (Bian ve Leung, 2014:4). Özellikle daha utangaç bireyler için çevrim içi (online) etkileşimler onların utangaçlık eğilimlerini aşabilmelerini sağlayan uygulamalardır. Bu uygulamalar sayesinde utangaç olan insanların yüz yüze iletişim yerine online iletişimde 
Aktaş, H., Y1lmaz, N. (2017). Smartphone addiction in terms of the elements of loneliness and shyness of university youth. International Journal of Social Sciences and Education Research, 3(1), 85-100.

daha başarılı olması mümkündür. Çünkü taraflar fiziksel olarak mevcut değildir ve utangaçlığa atfedilen yaygın duygular da muhtemelen ortaya çıkmayacaktır (Ward ve Tracey, 2004:612613). Böylece, insanların internette gezinerek bilgi elde etmesine olanak sağlayan ya da oyunlar gibi insanlara eğlenceye erişim imkanı veren akıllı telefonlar, utangaç insanların rahatsız oldukları durumlardan kaçınmasına katkıda bulunabilmektedir (Bian ve Leung, 2014:4).

Akıllı telefonların yaygın olarak benimsenmesi ve kullanımı gün geçtikçe artamasına rağmen özellikle cihazın aşırı kullanımı bazı sosyal sorunları araştırmak için yeni bir alan ortaya çıkarmıştır. Önceki çalışmalar cep telefonu ve internet bağımlılığına çok önem vermiş olmasına rağmen çok az araştırma özellikle akıllı telefon bağımlılığını araştırmıştır. Diğer ülkelerde olduğu gibi Türkiye'de kullanımı giderek artan akıllı telefonların kontrolsüz ve aşırı kullanımına ilişkin yapılımış olan çalışmalar sınırlı sayıdadır. Genel olarak akıllı telefon bağımlılık ölçeği'ni geçerlilik ve güvenilirlik açısından değerlendirmek, "akı1lı telefon satın alma tercihleri, akıllı telefon kullanımını etkileyen faktörler gibi çalışmalar bulunmaktadır (Balc1 ve Gülnar (2009); Ada ve Tatl1, (2012); Kwon vd. (2013). Alfawareh and Jusoh; Park and Park (2014); Demirci vd. (2014); Noyan vd. (2015); Şata vd. (2016)). Bu çalışmada bu alanda üzerinde fazla çalışılmamış olan akıllı telefon bağımlılığının psikolojik özellikler olan yalnızlık ve utangaçlık açısndan ilişkisi incelenmiştir. Ayrıca bu çalışma akıllı telefon kulllanım özellikleri, yalnızlık ve utangaçlığın akıllı telefon bağımlılığı üzerinde önemli bir etkiye sahip olup olmadığını ortaya koymuştur.

\section{Metodoloji}

Selçuk Üniversitesi İletişim Fakültesi öğrencilerinin akıllı telefon bağımlılıklarını yalnızlık ve utangaçlık açısından tespit etmek amacıyla Ocak, 2016 tarihinde bir saha araştırması yapı1mıştır. Araştırma evreninden basit rastlantısal örneklem yoluyla seçilen 320 öğrenciye yüz yüze görüşmeye dayalı anket uygulanmıştır. Hazırlanan anket formu, 50 ögrenci üzerinde ön teste (pre-test) tabi tutulmuş gerekli kontrol ve düzenlemeler yapıldıktan sonra uygulamaya hazır hale getirilmiştir. Veriler, eksik ve hatalı olanlar çıkartılarak 298 anketten elde edilmiş olup istatistik paket programı (SPSS 20.0) kullanılarak analiz edilmiştir. Katılımcıların akıllı telefon bağımlılıklarını yalnızlık ve utangaçlık açısından incelemek amacıyla Bian ve Leung (2014)'un çalışması temel alınarak 5 bölümlü bir anket formu hazırlanmıştır. Bu anket formunda Akıllı Telefon Bağımlılığı Ölçeği, Akıllı Telefon Kullanım Ölçeği, Utangaçlık Ölçeği ve Yalnızlık Ölçeği kullanılmıştır.

İlgili literatür taraması kapsamında aşağıda sıralanan araştırma sorularına cevap aranmıştır.

Araştırma Sorusu 1: Katılımcıların akıllı telefon bağımlılık düzeyi nedir?

Araştırma Sorusu 2: Akıllı telefon bağımlılığı ile katılımcıların yalnızlık düzeyi arasında ne tür bir ilişki vardır?

Araştırma Sorusu 3: Akıllı telefon bağımlılı̆̆ı ile katılımcıların utangaçlık düzeyi arasında ne tür bir ilişki vardır?

Araştırma Sorusu 4: Katılımcıların akıllı telefon kullanım özellikleri nasıl bir dağılım göstermektedir?

Araştırma Sorusu 5: Yalnızlık ve utangaçlık akıllı telefon bağımlılı̆̆ını etkilemekte midir? 
Aktaş, H., Yılmaz, N. (2017). Üniversite gençlerinin yalnızlık ve utangaçlık unsurları açısından akıllı telefon bağımlılığı. International Journal of Social Sciences and Education Research, 3(1), 85-100.

Araştırma Sorusu 6: Katılımcıların akıllı telefon bağımlılığı cinsiyete göre farklılaşmakta midir?

Araştırma Sorusu 7: Katılımcıların akı1lı telefon bağımlılı̆̆ yaşa göre farklılaşmakta mıdır?

Ayrıca bu çalışmanın katılımcı sayısının düşük olması, kadın ve erkek katılımcı sayısının eşit olmaması ve Konya Selçuk Üniversitesi İletişim Fakültesinde öğrenim görmekte olan öğrenciler arasında yapılmış olması gibi sınırlılıkları bulunmaktadır.

\section{Bulgular}

Selçuk Üniversitesi İletişim Fakültesinde eğitim gören öğrenciler üzerinde yapılan araştırma bulguları şöyle yer almaktadır.

\subsection{Katılimcllarin demografik özellikleri}

Katılımcıların demografik özelliklerine ilişkin bazı bulgular şu şekildedir:

Ankete katılan deneklerin cinsiyet bakımından \% 56.5'i kadın, \% 43.5'i erkektir. Katılımcıların yarısından fazlasını \% 68.9 gibi bir oranla 18-21 yaş aralığı oluşturmaktadır. Araştırmaya katılanların \% 30.1'i 22-25, \% 1,0'i 26 ve üzeri yaş grubunda yer almaktadır. Aylık Harcama Miktarınız ilgili soruya verilen cevaplar değerlendirildiğinde; katılımcıların büyük çoğunluğu \% 46.0'1 500 TL ve altı, \% 44,3'ü 501-1000 TL olduğunu belirtmişlerdir. Deneklerin \% 8.7'si 1001-1500 TL, \% 2.1'i 1501 TL ve üzerinde gelire sahiptir.

İkamet etme durumunuz nedir?" şeklindeki soruya katılımcıların \% 51.2'si yurtta kaldığını belirtmiştir. Diğer katılımcıların \% 33.9'u evde arkadaşlarımla, \% 11.1'i ailemle, \% 3.1'i evde yalnız, \% 0.7 ' si akrabalarımla kaldığı cevabında bulunmuşlardır.

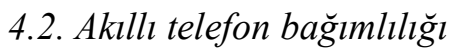

Akıllı telefon bağımlılığını belirlemek amacıyla hazırlanan 5'li likert tipi ölçekteki 17 maddeye verilen yanıtlar doğrultusunda faktör analizi uygulanmıştır (Cronbach's $\alpha$ katsayısı .882 olarak hesaplanmıştır). Faktör analizinde Varimax rotasyonlu tablo esas alınmış, minimum yükleme düzeyi 0,40 kriteri kullanılmıştır. Analizde 2 madde yüklenme değeri taşımadığı ya da minimum yüklenme büyüklüğünün çok altında olduğundan inceleme dışı bırakılmıştır. 
Aktaş, H., Y1lmaz, N. (2017). Smartphone addiction in terms of the elements of loneliness and shyness of university youth. International Journal of Social Sciences and Education Research, 3(1), 85-100.

Tablo 1. Katılımcıların akıllı telefon bağımlılığını belirlenmesine yönelik faktör analiz (Principal Component Analysis, Varimax Rotation)

\begin{tabular}{|c|c|c|c|}
\hline & $\begin{array}{c}\text { Faktör } \\
\text { Yükü }\end{array}$ & $\bar{X}$ & Sd. \\
\hline \multicolumn{4}{|l|}{ Vakit geçirme } \\
\hline Planladığım zamandan daha uzun süre akıllı telefonla vakit geçiririm. & .774 & 3,16 & 1,30 \\
\hline Akı1lı telefon kullanım miktarını azaltmayı düşünürüm. & .673 & 2,93 & 1,35 \\
\hline Akıllı telefonla daha az vakit geçirmeye çalışırım ama bunu başaramam. & .655 & 2,72 & 1,27 \\
\hline $\begin{array}{l}\text { Akıllı telefonla harcadığım zamanın doğrudan bir sonucu olarak okul/meslek/aile } \\
\text { vb. yaşamdaki verimliliğim azalır. }\end{array}$ & .635 & 2,72 & 1,26 \\
\hline Moralim bozuk olduğunda akıllı telefonu kendimi iyi hissetmek için kullanırım. & .540 & 3,08 & 1,35 \\
\hline Akıllı telefonla harcadığım zamandan dolayı ödevlerim ve notlarım kötü etkilenir. & .514 & 2,57 & 1,21 \\
\hline Arkadaşlarım /ailem akıllı telefon kullanımımdan şikâyetçi olur. & .470 & 2,38 & 1,27 \\
\hline $\begin{array}{l}\text { Başlangıçta yapmam gereken şeylerle ilgilenmek yerine akıllı telefon kullanmayı } \\
\text { tercih ederim. }\end{array}$ & .465 & 2,49 & 1,22 \\
\hline \multicolumn{4}{|l|}{ Endişe etme } \\
\hline $\begin{array}{l}\text { Akıllı telefonu açmadığımda ya da mesajları kontrol etmediğimde endişeli hissede- } \\
\text { rim. }\end{array}$ & .818 & 2,78 & 1,35 \\
\hline Kapsama alanı dışında olduğunda birinin beni arayıp aramadığı zihnimi işgal eder. & .740 & 2,92 & 1,37 \\
\hline $\begin{array}{l}\text { Akıllı telefonu kullanmadığımda ya da bunun hayalini kurduğumda kendimi endi- } \\
\text { şeli hissederim. }\end{array}$ & .656 & 2,01 & 1,19 \\
\hline $\begin{array}{l}\text { Akıllı telefon kullanmadığım zaman onu özler akıllı telefon kullanmaya devam } \\
\text { ederim. }\end{array}$ & .617 & 2,61 & 1,36 \\
\hline \multicolumn{4}{|l|}{ Olumsuz sonuçlar } \\
\hline $\begin{array}{l}\text { Akıllı telefonu bir toplantı/ders ya da tiyatro esnasında çalmaya başladığında daha } \\
\text { fazla sorun olmuştur. }\end{array}$ & .674 & 2,00 & 1,14 \\
\hline Akı1lı telefonla ne kadar zaman geçirdiğimi başkalarından gizlemeye çalışırım. & .620 & 1,66 & 1,05 \\
\hline Akıllı telefonla meşgul olmam bir soruna sebep olur. & .617 & 2,29 & 1,16 \\
\hline $\begin{array}{l}\text { Olmaması gereken zamanlarda akıllı telefonla uğraştığım için randevularıma geç } \\
\text { kalırım. }\end{array}$ & .523 & 1,88 & 1,08 \\
\hline Ak1llı telefonla yeterli zaman geçirmem. & .407 & 2,32 & 1,09 \\
\hline \multicolumn{4}{|l|}{ Kaiser-Meyer-Olkin (KMO) Örneklem Yeterliliği: .887 } \\
\hline Bartlett Testi $X^{2}: 2016,727 \quad$ df:153 ; p:000 & & & \\
\hline
\end{tabular}

Sonuçların değerlendirilmesinde Barlett testi ve Kaiser-Meyer-Olkin (KMO) testi kullanılmıştır. Barlett testine göre faktör analizine tabi tutulan yargılar ile ana grup arasında $(\mathrm{p}=, 000)$ anlamlı farklılık bulunmuştur. KMO değeri ise, 887 olarak hesaplanmıştır. Bu araştırmalardan elde edilen bulgular, ölçeğin bireylerin akıllı telefona bağımlılık düzeylerine ilişkin geçerli ve güvenilir ölçümler sağlayabildiğine yönelik kanttlar olarak değerlendirilmektedir. "Akıllı Telefon Bağımlığı”na ilişkin faktör analizi sonucunda ortaya çıkan bu üç faktör, toplam varyansın \% 52,79'unu açılamaktadır. 
Aktaş, H., Yılmaz, N. (2017). Üniversite gençlerinin yalnızlık ve utangaçlık unsurları açısından akıllı telefon bağımlılı̆̆. International Journal of Social Sciences and Education Research, 3(1), 85-100.

\subsection{Akull telefon kullanım özellikleri}

“Akıllı Telefon Kullanım Özelliklerini” belirlemek amacıyla hazırlanan 5'li likert tipi ölçekteki 15 yargıya (maddeye) verilen yanıtlar doğrultusunda faktör analizi uygulanmıştır (Ö1çeğin güvenilirliği 757 olarak hesaplanmıştır). Faktör analizinde Varimax rotasyonlu tablo esas alınmış, minimum yükleme düzeyi 0,40 kriteri kullanılmıştır.

Tablo 2. Akı1lı telefon kullanım özelliklerinin belirlenmesine yönelik faktör analiz (Principal Component Analysis, Varimax Rotation

\begin{tabular}{|c|c|c|c|}
\hline & $\begin{array}{l}\text { Faktör } \\
\text { Yükü }\end{array}$ & $\bar{X}$ & Sd. \\
\hline \multicolumn{4}{|l|}{ İnteraktiflik } \\
\hline Mesajlaşmak & ,847 & 4,10 & 0,98 \\
\hline Fotoğraf ve video çekmek & 639 & 4,07 & 1,16 \\
\hline Telefonla görüşme yapmak &, 546 & 3,94 & 0,95 \\
\hline Anlık ileti kullanmak & ,530 & 3,75 & 1,14 \\
\hline \multicolumn{4}{|l|}{ Faydalanma } \\
\hline Günlük yaşam hakkında bilgileri kontrol etmek & ,745 & 3,74 & 0,96 \\
\hline Haberleri görüntülemek & ,687 & 3,78 & 1,03 \\
\hline Sözlük & ,615 & 2,96 & 1,14 \\
\hline E- posta & ,603 & 2,94 & 1,23 \\
\hline E- kitap & 431 & 2,43 & 1,29 \\
\hline \multicolumn{4}{|l|}{ Bilgi/Eğlence } \\
\hline İnternette gezinmek & ,664 & 4,28 & 0,79 \\
\hline Araba motorunu kullanmak & ,639 & 4,07 & 0,81 \\
\hline Müzik dinlemek &, 531 & 4,26 & 0,95 \\
\hline Video izlemek & ,498 & 4,02 & 0,91 \\
\hline Oyun oynamak & 491 & 2,61 & 1,42 \\
\hline Sosyal ağ hizmetlerini kullanmak & ,437 & 4,26 & 0,97 \\
\hline \multicolumn{4}{|c|}{ Kaiser-Meyer-Olkin (KMO) Örneklem Yeterliliği: .796 } \\
\hline \multicolumn{4}{|l|}{ Bartlett Testi $\mathrm{X}^{2}: 827,456$ df:105 $\quad$; p:000 } \\
\hline
\end{tabular}

Yapılan analizde Barlett testi ve Kaiser-Meyer-Olkin (KMO) testi kullanılmıştır. Barlett testine göre faktör analizine tabi tutulan yargılar ile ana grup arasında $(\mathrm{p}=, 000)$ anlamlı farkl1l1k bulunmuştur. Faktörlerin Kaiser-Meyer-Olkin (KMO) örneklem yeterliliği ölçütü .796 olarak hesaplanmıştır. Oluşan tabloya göre tespit edilen üç faktör toplam varyansın yüzde 44 'ünü açıklamaktadır.

\subsection{Korelasyon analizi}

Çalışmanın bu bölümünde araştırmaya katılan üniversite öğrencilerinin "akıllı telefon bağımlılığ faktörleri ile yalnızlık ve utangaçlık" arasındaki ilişkinin düzeyini tanımlamak bakımından korelasyon analizinin sonuçları Tablo 3'te yer almaktadır. 
Aktaş, H., Y1lmaz, N. (2017). Smartphone addiction in terms of the elements of loneliness and shyness of university youth. International Journal of Social Sciences and Education Research, 3(1), 85-100.

Tablo 3. Akıllı telefon bağımlılığı faktörleri, yalnızlık ve utangaçlık arasındaki korelasyon analizi (Pearson r)

\begin{tabular}{|c|c|c|c|c|c|}
\hline & $\begin{array}{c}\text { Vakit Ge- } \\
\text { çirme }\end{array}$ & Endişe Etme & $\begin{array}{c}\text { Olumsuz So- } \\
\text { nuçlar }\end{array}$ & Yalnızlık & Utangaçlık \\
\hline Vakit Geçirme & 1 & & & & \\
\hline Endişe Etme &, $614(* *)$ & 1 & & & \\
\hline Olumsuz Sonuçlar &, $548(* *)$ &, $388(* *)$ & 1 & & \\
\hline Yalnızlık &, $192(* *)$ &, 087 &, $187(* *)$ & 1 & \\
\hline Utangaçlık &, $200(* *)$ &, $203(* *)$ &, $288(* *)$ &, $267(* *)$ & 1 \\
\hline
\end{tabular}

** 0,01 anlamlılık seviyesinde korelasyon (çift yönlü).

* 0,05 anlamlılık seviyesinde korelasyon (çift yönlü).

Akıllı telefon bağımlılığı faktörleri, yalnızlık ve utangaçlık arasındaki ilişki düzeyini tanımlamak bakımından korelasyon analiz sonuçları incelendiğinde; "vakit geçirme" ile "endişe etme" $(.614, \mathrm{p}<.01)$ ve "olumsuz sonuçlar" $(.548, \mathrm{p}<.01)$ arasında orta düzeyde pozitif anlamlı bir ilişki dikkat çekmektedir. Yine bu araştırma ile "endişe etme ile olumsuz sonuçlar" (.388, $\mathrm{p}<.01)$; "olumsuz sonuçlar ile utangaçlık" $(.288, \mathrm{p}<.01)$; "yalnızlık ile utangaçlık" arasında ise zayıf düzeyde pozitif anlamlı bir ilişkinin $(.267, \mathrm{p}<.01)$ olduğu bulgulanmıştır. Diğer bir ifade ile kişilerin endişe etmesi arttıkça olumsuz sonuçlar da artmaktadır. "Vakit geçirme ile "yalnızlık" (.192, p<.01) ve "utangaçlık" $(.200, \mathrm{p}<.01)$; "endişe etme ile utangaçlık" arasında çok zayıf pozitif yönde anlamlı bir ilişkinin $(.203, \mathrm{p}<.01)$ varlığ Korelasyon analizi ile tespit edilmiştir.

\subsection{Akıllı telefon bă̆ımlılı̆̆ına etki eden değişkenlerin doğrusal (linear) regresyon analizi}

Bu çalışmada bağımlı (Yordanan) değişken üzerinde anlamlı bir etkiye sahip olan bağımsız (Yordayıcı) değişkenlerin yer aldığı çoklu doğrusal regresyon analizi gerçekleştirilmiştir. Modellerde korelasyon katsayılarının vermiş olduğu bilgiler 1şığı altında, bağımlı değişkenin ilişkili olduğu değişkenler ile regresyon analizi yapılmıştır. Araştırmanın yordanan değişkeni olarak kabul edilen "akıllı telefon bağımlılı̆ğ" ile yordayıcı değişkenler olarak "bilgi/eğlence, interaktiflik, utangaçlık ve yalnızlık" değişkenlerinin arasındaki ilişkinin incelenmesinde, öncelikle çoklu doğrusal regresyon analizinin gerektirdiği varsayımlar kontrol edilmiştir. Akıllı Telefon Kullanım Ölçeği üç alt boyuttan (İnteraktiflik, Faydalanma ve Bilgi/Eğlence) oluşmaktadır. Akıllı Telefon Kulanımı'nın alt boyutu olan "faydanlanma"nın akıllı telefon bağımlılığını yordama gücü istatistiksel olarak anlamlı $(\mathrm{r}=, 16>, 05)$ bulunmadığı için devre dışı bırakılıp İnteraktiflik ve Bilgi/Eğlence faktör boyutları ile yeniden yapılmıştır.

Model 1'de yer alan VIF değerleri 1,321'dir. Bu değer (virgülden sonraki ilk iki rakam) 10'dan yüksek olduğu için bu bağımsız değişkenlerden sadece birinin analize dahil edildiği diğeri analiz dışında bırakılmıştır. Analiz Bilgi/Eğlence, Yalnızlık ve Utangaçlık bağımsız değişkenleri ile yeniden yapılmıştır. 
Aktaş, H., Yılmaz, N. (2017). Üniversite gençlerinin yalnızlık ve utangaçlık unsurları açısından akıllı telefon bağımlılı̆̆. International Journal of Social Sciences and Education Research, 3(1), 85-100.

Tablo 4. Bilgi/Eğlence, Utangaçlık ve Yalnızlık yordayıcılarının akıllı telefon bağımlılığını yordamasına ilişkin çoklu regresyon analizi

\begin{tabular}{|c|c|c|c|c|c|c|c|c|c|c|c|c|}
\hline \multirow{2}{*}{$\begin{array}{c}\text { Yordayıcı } \\
\text { (Bağımsız De- } \\
\text { ğișkenler) }\end{array}$} & \multicolumn{2}{|c|}{ 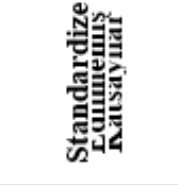 } & \multirow{2}{*}{ 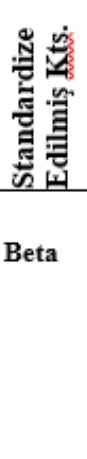 } & \multirow{2}{*}{$\underline{\mathbf{t}}$} & \multirow{2}{*}{ Sig. } & \multirow{2}{*}{$\mathrm{R}^{2}$} & \multirow[b]{2}{*}{ 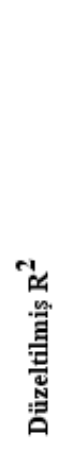 } & \multirow{2}{*}{$\mathbf{F}$} & \multirow{2}{*}{ Sig. } & \multicolumn{2}{|c|}{$\begin{array}{c}\text { İç İlisski İsta- } \\
\text { tistikleri }\end{array}$} & \multirow[b]{2}{*}{ 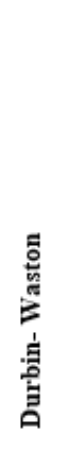 } \\
\hline & B & $\begin{array}{c}\text { Std. } \\
\text { Hata }\end{array}$ & & & & & & & & 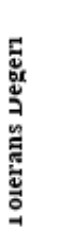 & $\begin{array}{l}\text { '志 } \\
\text { คั̀ } \\
\text { 岁 }\end{array}$ & \\
\hline \multicolumn{6}{|l|}{ Model 1} &, 123 &, 116 & 19,983 &, 000 & & & \\
\hline Sabit & 0,863 & 275 & & 3,144 & 002 & & & & & & & \\
\hline İnteraktiflik & 149 &, 061 &, 155 & 2,433 & .016 & & & & & .757 & 1,321 & 1,791 \\
\hline Bilgi/Eğlence & 291 &, 075 & 247 & 3,879 &, 000 & & & & & .757 & 1,321 & \\
\hline \multicolumn{6}{|l|}{ Model 2} &, 162 &, 154 & 18,419 &, 000 & & & \\
\hline Sabit &,- 341 & 442 & &,- 771 & 441 & & & & & & & \\
\hline Bilgi/Eğlence &, 337 &, 065 &, 286 & 5,203 &, 000 & & & & & 976 & 1,025 & 1,788 \\
\hline Utangaçlık & 270 &, 083 &, 184 & 3,243 &, 001 & & & & & 916 & 1,092 & \\
\hline Yalnızlık &, 262 &, 125 &, 118 & 2,099 &, 037 & & & & & 924 & 1,082 & \\
\hline
\end{tabular}

Model 2'de yer alan VIF değerleri 1,092'nin (1,082/1,025) altında ve tüm değişkenlerin tolerans değerleri ,916'dan yüksek olduğundan çoklu bağlantı bulunmamaktadır. Durbin-Watson katsayı otokorelesyonu test etmede kullanılmaktadır. Durbin-Watson değerinin 1,5 ile 2,5 arasında olması beklenir. Bu modelde Durbin-Watson katsayıs1 1,788 civarındadır. Dolay1sıyla otokorelasyon sorunu da bulunmamaktadır. Bilgi/Eğlence, Yalnızlık ve Utangaçlık (Bağımsız değişken) özelliklerin Akıllı Telefon Bağımlılı̆̆ı (Bağımlı değişken) üzerindeki etkilerini ortaya koymak üzere oluşturulan regresyon modelinin F değeri 18.419, anlamlılık düzeyi $\mathrm{p}<0.01$ 'dir.

\subsection{Băğımsız örneklem T testi}

Katılımcıların akıllı telefon bağımlılığ faktörlerinin cinsiyet değişkenine göre anlamlı biçimde farklılık gösterip göstermediğini ortaya koyabilmek amacıyla bağımsız örneklem t testi aracılığıyla analiz edilmiştir. Analiz sonucunda cinsiyet ile "vakit geçirme" ( $\mathrm{t}=1,99 ; \mathrm{sd}$. = 406; $\mathrm{p}<0.05$ ) arasında anlamlı bir farklılaşmanın olduğu ortaya çıkmaktadır. Sonuçlara göre kadın öğrencilerin ortalaması ( $\bar{X}=2.87$ ) erkek öğrencilerin ortalamasından $(\bar{X}=2.66)$ anlamlı biçimde daha yüksektir. "endişe etme" faktörünün cinsiyet ile arasında $(t=1,03 ; \mathrm{sd} .=306 ; \mathrm{p}<0.05)$ anlamlı bir farklılaşma meydana getirdiği gözlenmektedir. Bu sonuçlara göre kadın öğrenciler 2.76 ortalama değeri ile erkek öğrencilerden $(\bar{X}=2.40)$ endişe etmeye daha fazla önem vermektedir. Tabloyu değerlendirdiğimizde erkek katılımcıların olumsuz sonuçlar ortalaması $(\bar{X}=2.14)$ kadınlardan $(\bar{X}=1.93)$ daha yüksektir. 
Aktaş, H., Yılmaz, N. (2017). Smartphone addiction in terms of the elements of loneliness and shyness of university youth. International Journal of Social Sciences and Education Research, 3(1), 85-100.

Cinsiyet değişkeni açısından akıllı telefon kullanım özelliklerinin faktörleri arasındaki farklılaşma sonucunda ise; cinsiyet ile interaktiflik faktörü arasında anlamlı bir farklılaşma bulunmaktadır $(\mathrm{t}=3,11 ; \mathrm{sd} .=0,73 ; \mathrm{p}<0.05)$. Kadın öğrencilerin ortalaması $(\bar{X}=3.97)$ erkek öğrencilerin ortalamasından $(\bar{X}=3.71)$ anlamlı biçimde daha yüksektir.

Cinsiyet ile "faydalanma ve bilgi/eğlence" faktörleri arasında anlamlı bir farklılaşmanın olmadığı bulgulanmıştır $(\mathrm{t}=-2,58$; sd. $=946 ; \mathrm{p}>.05)$. Erkek katılımcıların faydalanma ortalaması oranı $(\bar{X}=3.19)$ kadınlardan $(\bar{X}=3.15)$ biraz daha yüksek olmasına rağmen bu oran anlamlı fark oluşturacak düzeyde değildir. Aynı şekilde bilgi/eğlence ortalaması açısından da erkek öğrencilerin oranı biraz daha yüksektir ancak bu oran anlamlı bir fark oluşturmamaktadır. Bir başka anlatımla kadınlar ve erkekler bu faktöre verdikleri önem bakımından birbirine yakın değerlere sahiptirler.

Aynı şeklide yalnızlık ve utangaçlık düzeylerinin de cinsiyete göre farklılaşıp farklılaşmadığını ortaya koymak için yapılan analiz sonucunda anlamlı bir farklılaşma meydana getirmediği görülmektedir $(\mathrm{p}>0,05)$.

\subsection{Akıllı telefon bă̆ımlılı̆̆ı ile Yaş arasında Tek Yönlü Anova Testi}

Katılımcı üniversite öğrencilerinin "akıllı telefon bağımlılığı” düzeylerinin yaşa göre farkl11ık gösterip göstermediğini ortaya koyabilmek amacıyla tek yönlü varyans analizi (ANOVA) uygulanmıştır.

Tablo 5. Katılımcıların yaşları ile akıllı telefon bağımlılığına verdikleri önem arasındaki farklılaşma

\begin{tabular}{|c|c|c|c|c|}
\hline Yaş & $\mathbf{N}$ & $\overline{\boldsymbol{X}}$ & Sd. & ANOVA \\
\hline $18-21$ & 199 & 2,64 & 0,69 & F=3.38 \\
\cline { 1 - 3 } $22-25$ & 87 & 2,43 & 0,71 & Df. $=2$ \\
26 ve üstü & 3 & 2,15 & 0,60 & P $<0.05$ \\
\hline
\end{tabular}

Yapılan tek yönlü varyans analizi sonucunda katılımcıların yaşları ile akıllı telefon bağımlılığ 1 arasında anlamlı bir farklılık bulunmuştur $(\mathrm{F}=3.38$, s.d=2, $\mathrm{p}<0.05)$. Farklılaşmanın hangi yaş grupları arasında olduğunu ortaya koymak amacıyla yapılan Tukey testi sonucunda 18-21 yaş grubu arasındaki katılımcılar ile 22-25 yaş grubundaki katılımcılar arasında olduğu ortaya çıkmaktadır. Ancak diğer yaş grupları arasında ise anlamlı bir farklılaşma bulunmamaktadır $(\mathrm{p}>0.05)$. İlgili test sonucunda elde edilen betimleyici istatistik tablosuna göre 1821 yaş grubunun ortalaması $(\bar{X}=2,64), 22-25$ yaş $(\bar{X}=2,43)$ ile 26 ve üstü yaş grubun ortalamasından $(\bar{X}=2,15)$ anlamlı biçimde daha yüksektir.

\section{Sonuç}

Günümüzün en çok tercih edilen ve kullanılan iletişim aracı olan akıllı telefonlar, tüm dünyada olduğu gibi ülkemizde de gündelik yaşamın ayrılmaz bir parçası olarak yerini almıştır. Hemen her yaşta bireyin özellikle de günümüz gençlerinin akıllı telefonları aşırı kullanımı teknolojiye bağımlı bir gençlik ortaya çıkarmıştır. Gençlerin, gün geçtikçe de kullanımı gittikçe artan akıllı telefonların yan etkilerine daha açık oldukları anlamına gelmektedir. Özellikle psikolojik açıdan en önemli yan etiklerinden biri de akıllı telefon bağımlılığıdır. Şu bir 
Aktaş, H., Yılmaz, N. (2017). Üniversite gençlerinin yalnızlık ve utangaçlık unsurları açısından akıllı telefon bağımlılığı. International Journal of Social Sciences and Education Research, 3(1), 85-100.

gerçektir ki bir cihaza böyle bir bağımlılığın olması ayrıca pek çok riski de beraberinde getirmektedir. Sonuç olarak genç ve dinamik bir nüfusa sahip ülkemiz için akıllı telefon bağımlılığına ve beraberindeki risklere son derece açık olduğumuz söylenebilir.

$\mathrm{Bu}$ çalışma ile de akıllı telefonu yoğun biçimde kullanan üniversite öğrencilerinin akıllı telefon bağımlılık düzeyleri, akıllı telefon bağımlılığının yalnızlık ve utangaçlık ile olan ilişkisi küçük bir örneklem üzerinde ortaya konmaya çalışılmıştır.

Araştırma sonuçlarına göre deneklerin akıllı telefon bağımlılığında etkili olan 3 faktör ortaya çıkmıştır. Faktörler, toplam varyansın \% 52,79'unu açıklamaktadır. Analiz sonucunda ortaya çıkan ilk ve en önemli faktör vakit geçirmedir.

Katılımcıların "akıllı telefon bağımlılık" düzeyleri ile ilgili betimleyici istatistik sonuçları olarak ilk sırayı 3.53 aritmetik ortalama değeriyle "akıllı telefon kullanacağım zamanı kendim belirlerim" gelmektedir. Bu sonuca göre katılımcılar, akıllı telefonu ne zaman kullanıp ne zaman kullanmayacağını kendisi belirlemektedir. Yine katılımcıların en çok puan verdikleri "planladığım zamandan daha uzun süre akıllı telefonla vakit geçiririm $(\bar{X}=3.16)$ " ve "moralim bozuk olduğunda akıllı telefonu kendimi iyi hissetmek için kullanırım $(\bar{X}=3.08)$ " diğer üst sırada yer alan maddeleri oluşturmaktadır. Bunun yanında araştırmada "olmaması gereken zamanlarda akıllı telefonla uğraştığım için randevularıma geç kalırım" $(\bar{X}=1,88)$ ile "akıllı telefonla ne kadar zaman geçirdiğimi başkalarından gizlemeye çalışırım” ( $\bar{X}=1,66)$ katılımcılar tarafından daha az puan verilen maddeler olarak karşımıza çıkmaktadır.

“Akı1lı telefon kullanım özellikleri”nin belirlenmesine yönelik faktör analizi sonucunda ise tespit edilen üç faktör toplam varyansın yüzde 44'ünü açıklamaktadır. İnteraktiflik" faktörü (mesajlaşmak, fotoğraf ve video çekmek, telefonla görüşme yapmak, anlık ileti kullanmak) toplam varyansın \% 25,04'ünü açıklamaktadır.

Yapılan araştırma sonucunda elde edilen verilere göre; 4.28 aritmetik ortalama değeriyle "internette gezinmek" katılımcıların en çok puanladığı özelik olarak karşımıza çıkmaktadır. Aynı ortalama değerlerine sahip "sosyal ağ hizmetlerini kullanmak ve müzik dinlemek $(\bar{X}=$ 4,26) katılımcıların en fazla puan verdikleri maddeleri oluşturmaktadır. Yine katılımcıların yüksek oranda puan verdikleri diğer maddeler "mesajlaşmak", "arama motorunu kullanmak" ile "video izlemek" olarak sıralanmaktadır. Bunların yanı sıra son sıralarda 2,96 ortalama değeri ile "sözlük", 2,94 ortalama puanı ile "e- posta" ile "oyun oynamak" ve 2,43 oranda bir ortalama ile "e- kitap" katılımcılar tarafından daha az puan verilen akıllı telefon kullanım özellikleri yer almaktadır.

Çalışmanın amacına yönelik olarak katılımcıların akıllı telefon bağımlılık faktörleri ile yalnızlık ve utangaçlık arasındaki ilişki net bir biçimde ortaya konmuştur. Bu bağlamda, yapılan korelasyon sonucunda en güçlü ilişkilerin "vakit geçirme" ile "endişe etme" (.614, p<.01) ve "olumsuz sonuçlar" $(.548, \mathrm{p}<.01)$ arasında olduğu dikkat çekmektedir. Buna göre soruları yanıtlayan katılımcıların akıllı telefon ile vakit geçirmesi arttıkça endişe etmeleri ve olumsuz sonuçlar yaşamalarında da bir artış yaşanmaktadır. Öte yandan diğer faktörler arasında da pozitif anlamlı ilişkiler söz konusu iken "endişe etme" faktörünün "yalnızlık" ile bir ilişkisi olmadığ 1 tespit edilmiştir.

Regresyon analizi sonuçları incelendiğinde iki model test edilmektedir. Model 1'de yer alan "ak1llı telefon kulanımı"nın alt boyutu olan "faydanlanma"nın "ak1llı telefon bağımlılığ 
Aktaş, H., Y1lmaz, N. (2017). Smartphone addiction in terms of the elements of loneliness and shyness of university youth. International Journal of Social Sciences and Education Research, 3(1), 85-100.

(yordanan)"nı yordama gücü istatistiksel olarak anlamlı $(\mathrm{r}=, 16>, 05)$ bulunmadığ için devre dışı bırakılmıştır. Ancak model 1 değerlendirildiğinde bağımsız değişkenler (yordayıcı) arasında çoklu bağlantı söz konusudur. Varyans artış faktör değerinin virgülden sonraki ilk iki rakamı 10'dan yüksek olduğu için bu bağımsız değişkenlerden sadece biri analize dahil edilip diğeri ise analiz dışında bırakılmıştır. "İnteraktiflik" değişkeni utangaçlık değişkeni ile istatistiksel olarak anlamlı $(\mathrm{r}=, 21>, 05)$ bulunmadığ 1 için "bilgi/eğlence" yordayıcısı model 2'de kullanılmıştır. Analiz "bilgi/eğlence, yalnızlık ve utangaçlık” bağımsız değişkenleri ile yeniden yapılmıştır.

Yapılan regrasyon analizinde yordayıcı değişkenler ile yordanan değişken arasındaki ilişkinin yönü, düzeyi ve anlamlılık derecesi dikkate alındığında, pozitif yönde "zayıf" ve "çok zayıf" düzeyde anlamlı ilişkilerin olduğu tespit edilmiştir. Analiz sonuçlarına göre Bilgi/Eğlence $(\beta=0.286 ; p<0.05) ;$ Utangaçlık $(\beta=0.184 ; p<0.05)$ ve Yalnızlık $(\beta=0.118 ; p<0.05)$ yordayıcı değişkenlerinin yordanan değişken olan akıllı telefon bağımlılığını pozitif yönde ve anlamlı düzeyde yordadığı görülmektedir. Bu bağımsız değişkenlerin anlamlı bir etkiye sahip olduğu tespit edilmiştir. Yapılan çoklu doğrusal regresyon analizi sonucunda elde edilen R2 değeri regresyon eşitliğinin açıklama gücünü ifade etmektedir. Bu değer 0 ile 1 arasında değişmekte ve yüksek R2 değeri yüksek açıklama oranına işaret etmektedir (Hair vd. 2010:152). Araştırma sonucunda kurulan modeller arasında en uygun modelin \%16 (R2)açıklama oranı ile ikinci model olduğu sonucuna varılmıştır. Geriye açıklanamayan \% 84'lük bir kısım bulunmaktadır.

Katılımcıların akıllı telefon bağımlılığı faktörlerinin cinsiyet değişkenine göre anlamlı biçimde farklılık gösterdiği yani kadın öğrencilerin vakit geçirme ve endişe etme düzeylerinin erkek öğrencilerden anlamlı derecede yüksek olduğu bu çalışmanın bulguları arasında yer almaktadır. Ancak olumsuz sonuçlar düzeyinde ise erkek katılımcıların ortalamasının kadın katılımcılardan daha yüksek olduğu görülmektedir. Yani erkeklerin olumsuz sonuçlara verdiği önem daha fazladır. Çalışmada öğrencilerin cinsiyetine bağlı olarak vakit geçirme, endişe etme ve olumsuz sonuçlar faktörlerine verdikleri önem farkl1lık göstermektedir.

Cinsiyet değişkeni açısından akıllı telefon kullanım özelliklerinin faktörleri arasındaki farklılaşma sonucunda ise; cinsiyet ile interaktiflik faktörü arasında anlamlı bir farklılaşma bulunmaktadır. Kadın öğrencilerin ortalaması $(\bar{X}=3.97)$ erkek öğrencilerin ortalamasından $(\bar{X}$ $=3.71$ ) anlamlı biçimde daha yüksektir. Cinsiyet ile "faydalanma ve bilgi/eğlence" faktörleri arasında anlamlı bir farklılaşmanın olmadığı bulgulanmıştır. Bir başka anlatımla kadınlar ve erkekler bu faktöre verdikleri önem bakımından birbirlerine yakın ortalamalara sahiptir. Aynı şeklide yalnızlık ve utangaçlık düzeylerinin de cinsiyete göre farklılaşıp farklılaşmadığı ortaya koymak için yapılan analiz sonucunda anlamlı bir farklılaşma meydana getirmediği görülmektedir. Buna göre her cinsiyetten kendisini yalnız ve utangaç hisseden bireyler olabilir sonucu ortaya çıkmaktadır.

Yapılan tek yönlü varyans analizi sonucunda katılımcıların yaşları ile akıllı telefon bağıml1lı̆̆ sında olduğunu ortaya koymak amaciyla yapılan Tukey testi sonucunda 18-21 yaş grubu arasındaki katılımcılar ile 22-25 yaş grubundaki katılımcılar arasında olduğu ortaya çıkmaktadır. Ancak diğer yaş grupları arasında ise anlamlı bir farklılaşma bulunmamaktadır. 
Aktaş, H., Yılmaz, N. (2017). Üniversite gençlerinin yalnızlık ve utangaçlık unsurları açısından akıllı telefon bağımlılı̆̆. International Journal of Social Sciences and Education Research, 3(1), 85-100.

Son yıllarda insanların online olarak iletişim kurma sayılarında önemli artış söz konusudur. Böylece, insanların internette gezinerek bilgi elde etmesine ya da yüz yüze iletişim yerine sosyal ağ uygulamaları ile online iletişim kurmasına olanak veren akıllı telefonlar, utangaç ya da yalnız insanların ilk başvurdukları cihazlar olmaktadır. Sonuç olarak, araştırmanın örnekleminin tüm evreni temsil etmeyip Selçuk Üniversitesi İletişim Fakültesi öğrencilerinden oluşması çalışmanın önemli sınırlılığıdır. Benzer araştırmaların daha farklı ve daha geniş örneklemler üzerinde gerçekleştirilmesi araştırma sonuçlarından genelleme yapılmasına olanak sağlayacaktır. Bu tür çalışmalar, Türkiye' deki literatürün çeşitlilik göstermesine ve zenginleşmesine katkıda bulunacaktır.

\section{Kaynakça}

Alfawareh, H.M. and Jusoh, S. (2014). Smartphones Usage Among University Students: Najran Un1versity Case, International Journal of Academic Research Vol. 6. No. 2.pp.321-326.

Balcı, Ş. ve Gülnar, B. (2009). Üniversite Öğrencileri Arasında İnternet Bağımlılı̆̆ı ve İnternet Bağımlılarının Profilli, Selçuk Üniversitesi İletişsim Fakültesi Akademik Dergisi, 6, 1, 5-22.

Bian, M. and Leung, L. (2014). Linking Loneliness, Shyness, Smartphone Addiction Symptoms, and Patterns of Smartphone Use to Social Capital, Social Science Computer Review, 1-19.

Choudrie, J.; Pheeraphuttharangkoon, S.; Zamani, E.; George, G. (2014), Investigating the Adoption and Use of Smartphones in the Uk: a Silver-Surfers Perspective, Twenty Second European Conference on Information Systems, Tel Aviv.

Chun, H.; Lee, H. and Kim, D. (2012). The Integrated Model of Smartphone Adoption: Hedonic and Utilitarian Value Perceptions of Smartphones Among Korean College Students, Cyberpsychology, Behavior, And Soclal Networking Volume 15, Number 9.

Griffiths, M. (2003). Internet Gambling: Issues, Concerns, and Recommendations, Cyberpsychology \& Behavior, Volume 6, Number 6, pp.557-568.

Hair, J. F. Jr.; Black, W. C.; Babin, B. J.; Anderson, R. E. (2010). Multivariate Data Analysis, 7.Edition, Pearson Education, New Jersey.

Huan, V. S.; Ang, R.P.;Chong, W. H.; Chye, S. (2014). The Impact of Shyness on Problematic Internet Use: The Role of Loneliness, The Journal of Psychology, 2014, 148(6), pp. 699-715.

Jin, B. and Park, N. (2012), Mobile voice communication and loneliness: Cell phone use and the social skills deficit hypothesis, New Media \& Society, 15(7), pp.1094-1111.

Jin, B.S.; Yoon, S.H. and Ji, Y. G. (2013), Development of a Continuous Usage Model for the Adoption and Continuous Usage of a Smartphone, Intl. Journal of Human-Computer Interaction, 29: 563581 .

Kılınç H. ve Seher, A.S. (2005). Ergenlerde Yalnızlık ve Bilişsel Çarpıtmalar, Ankara University, Journal of Faculty of Educational Sciences, year:, vol: 38, no: 2, 69-88.

Kim, D.; Lee, Y.; Lee, J.; Nam, J.K. and Chung,Y. (2014). Development of Korean Smartphone Addiction Proneness Scale for Youth, Plos One, Volume 9, Issue 5.

Chen, K.; Chen, J. V. and Yen, D. C. (2011). Dimensions of self-efficacy in the study of smart phone acceptance, Computer Standards \& Interfaces 33 (2011) 422-431.

Chun, H.;Lee, H. and Kim, D. (2012). The Integrated Model of Smartphone Adoption: Hedonic and Utilitarian Value Perceptions of Smartphones Among Korean College Students, Cyberpsychology, Behavior, And Soclal Networking Volume 15, Number 9. 
Aktaş, H., Y1lmaz, N. (2017). Smartphone addiction in terms of the elements of loneliness and shyness of university youth. International Journal of Social Sciences and Education Research, 3(1), 85-100.

Demirci, K.; Orhan, H. ; Demirdas, A. ; Akpinar, A.; Sert, H. (2014). Validity and Reliability of the Turkish Version of the Smartphone Addiction Scale in a Younger Population, Klinik Psikofarmakoloji Bülteni, Cilt: 24, Sayı: 3, 2014 / Bulletin of Clinical Psychopharmacology, Vol: 24, N.:3.

Kwon, M.; Kim, D.J.; Cho, H., Yang, S. (2013). The Smartphone Addiction Scale: Development and Validation of a Short Version for Adolescents, Plos One, Vol. 8 Issue 12, pp.1-7.

Kwon, M.; Lee, J.Y.; Won, W.Y.; Park, J.W.; Min, J.A., et al. (2013). Development and Validation of a Smartphone Addiction Scale (SAS) PloS one 8(2).

Leung, L. (2007). Leisure Boredom, Sensation Seeking, Self-esteem, Addiction Symptoms and Patterns of Mobile Phone Use.

Noyan, C. O.; Enez Darçın, A.; Nurmedov, S.; Yılmaz, O.; Dilbaz, N. (2015). Akıllı Telefon Bağımlılı̆̆ Ölçeğinin Kısa Formunun Üniversite Öğrencilerinde Türkçe Geçerlilik ve Güvenilirlik Çalışması.

Park, C. and Park, Y. R. (2014). The Conceptual Model on Smart Phone Addiction among Early Childhood, International Journal of Social Science and Humanity, Vol. 4, No. 2.

Perlman, D. ve Peplau, L.A. (1984). Loneliness Research: A Survey of Empirical Findings, L A Peplau and S Goldston (eds), Preventing the Harmful Consequences of Severe and Loneliness, U.S. Government Printing Office, pp.13-46.

Pilkonis, P.A. (1977 ). The Behavioral Consequences of Shyness, J Personality, 45:596-611.

Russell, D.; Peplau, L. A. and Cutrona, C. E. (1980). The Revised UCLA Loneliness Scale: Concurrent and Discriminant Validity Evidence, Journal of Personality and Social Psychology, 39 (3), 472480 .

Şata, M.; Çelik, İ.; Ertürk, Z.; Taş, U.E. (2016). Akıllı Telefon Bağımlılı̆̆ı Ölçeği’nin (ATBÖ) Türk Lise Öğrencileri İçin Uyarlama Çalışması, Eğitimde ve Psikolojide Ölçme ve Değerlendirme Dergisi Journal of Measurement and Evaluation in Education and Psychology, 7(1);156-169.

Uzgören, E.; Mehmet, Ş.; Yiğit, Ü. (2013), Üniversite öğrencilerinin cep telefonu Talebinde israfa yönelik Davranışlarının analizi -Dumlupınar Üniversitesi Öğrencilerine Yönelik Bir Uygulama- Süleyman Demirel Üniversitesi İktisadi ve İdari Bilimler Fakültesi Dergisi, C.18, S.1, s.29-44.

Ward, C.C. and Tracey, J. G. (2004). Relation of Shyness with Aspects of Online Relationship İnvolvement, Journal of Social and Personal Relationship, Vol. 21(5), pp. 611-623.

Yüksel, G. (2002). Üniversite Öğrencilerinin Utangaçlık Düzeylerini Etkileyen Faktörler, G.Ü. Gazi Eğitim Fakültesi Dergisi Cilt 22, Sayı 3, pp. 37-57.

IDC, "Worldwide Smartphone 2014-2018 Forecast Update", Mart-2014, http://www.idc.com/getdoc.jsp?containerId $=247140$

The Online PC Magazine Encyclopedia, http://www.pcmag.com/encyclopedia/term/51537/smartphone

Poushter, J. (2016), Smartphone Ownership and Internet Usage Continues to Climb in Emerging Economies, http://www.pewglobal.org/2016/02/22/smartphone-ownership-and-internet-usage-continues-to-climb-in-emerging-economies/ 
Aktaş, H., Yılmaz, N. (2017). Üniversite gençlerinin yalnızlık ve utangaçlık unsurları açısından akıllı telefon bağımlılığı. International Journal of Social Sciences and Education Research, 3(1), 85-100.

\section{Extended Abstract in English}

Smartphones which combine cell phone and palmtop computer technology into a single device are popular technological tools of today. Increased use of these tools of getting under our control almost all the time has outpaced other mobile digital devices. As mentioned before, with smartphones not establish only verbal communication. Also, this tools especially allow the use of intensive, especially for young people of applications such as access to internet, texting, video talk, sharing music, videos and photos. In particular, since more lonely and shy individuals are reluctant to talk to others in face-to-face communication they use applications on smartphones and they prefer to communicate with people by texting. In this case, lonely and shy individuals lead to spend more time with smartphones.

As well as lonely and shy individuals, university students' within the user location and main target group of the new generation of technology thanks to interest and curiosity for communication and information technology are rapidly increasing duration of use daily tools which have higher functionality such as smartphones. Long-term usage of this tools cause the issue of some psychological. One of these problems is smartphone addiction. Excessive use of the internet and smartphones has an important role such a in experience addiction. The purpose of this study is to examine smartphone addiction level in terms of shyness and loneliness. The sample of the study consists of students in college who are smartphone users and studying at Communication Faculty of Selcuk University. In January, a field research was conducted. 320 students who selected through simple random sampling from the universe of research carried out face-to-face interview-based questionnaire. The data were obtained from 298 survey by removing missing and incorrect data and using statistical package (SPSS 20.0) were analyzed. A questionnaire with 5 sections that based on Bian and Leung (2014)'s study was prepared in order to examine smartphone addiction in terms of loneliness and shyness of participants. In the study, the data will be obtained using Smart Phone Addiction Scale, UCLA Loneliness Scale and Shyness Scale. In the light of the data obtained, in analyses such as factor analysis, correlation analysis and regression analysis were used. According to the results of the analysis; students use less to play the game and read e-books while using a purpose to more surf the web, to use social networking services and listen to music. Smart phone addiction a significant positive correlation between shyness and loneliness factors. There is a significant positive correlation between loneliness and shyness with smart phone addiction factors. Also "information/the entertainment, shyness and loneliness of the differentiating variables makes it different which is variable positively and significantly, it is observed that smartphone addiction. In addition, the dependent variables in the regression analysis are positively and significantly affected in the independent variable. The other finding, in the importance they give to factors

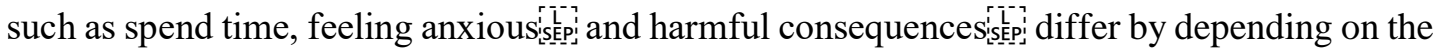
gender of the students. According to gender the level of loneliness and shyness is also observed that a meaningful differentiation does not occur.

In recent years, there is a significant increase in the number of people communicating online. Thus, smartphones that allow to communicate online with social networking applications of people instead of face to face communication or to obtain information by surfing the internet is the first device that is used for shy or lonely people 